\title{
2. Origins, Precedence and Social Order in the Domain of Ina Ama Beli Darlari
}

\author{
Susana Barnes
}

Since 1999, communities across Timor-Leste have been engaged in what some observers have described as a 'resurgence of custom'1 (Hicks 2007). This resurgence is most vividly associated with the rebuilding of sacred ancestral houses (Tetun: uma lulik), which were destroyed, abandoned or fell into disrepair during the course of the Indonesian military invasion and occupation. The reconstruction of these social and symbolic structures has occurred hand in hand with numerous other processes of restoration and renewal including: a return to settlements of 'origin' after years of displacement; the physical and/ or symbolic laying to rest of the dead and disappeared at ancestral burial sites; and renewed participation in communal ceremonies and rituals associated with the agricultural calendar. The time, effort and resources entailed in these rituals of return and renewal suggest that such actions are more than a simple reaffirmation of self-esteem following centuries of foreign domination. They involve the rearticulation of distinct forms of sociality structured around networks of kinship and alliance, closely tied to specific claims to land and access to natural resources (Bovensiepen 2009; Fitzpatrick and Barnes 2010; McWilliam 2006, 2007, 2008; Meitzner Yoder 2005; Palmer 2007).

Underpinning the social and spatial relations invoked by rituals of restoration and renewal are distinct principles and practices that have displayed considerable adaptive capacity and resilience in the face of historical processes of encompassment such as Portuguese colonialism and the Indonesian military occupation (Babo-Soares 2004; Fitzpatrick and Barnes 2010; Fitzpatrick et al. 2008; Hohe 2002; Traube 2007). Key amongst these principles are those relating to 'origins' and 'precedence' (Fitzpatrick and Barnes 2010; Fitzpatrick et al. 2008; Hohe 2002; Molnar, this volume; Traube 2007). Precedence describes a concatenation of relationships where the relative status of a person or group is conceptualised and defined by reference to their proximity to a common point of derivation or 'origin' (Fox 1994; Lewis 1996; Vischer 2009). What constitutes a common point of derivation or origin might be the subject of considerable

\footnotetext{
1 There is some debate in Timor-Leste today regarding the nature and role of 'custom' or 'culture' in contemporary society. Certain customary practices have been criticised for being rooted in the past, for being patriarchal and unequitable, while others have been extolled as providing people with a sense of meaning, order and value. See, for example, McWilliam (2005); Trindade (2008); Brown (2009).
} 
debate and is frequently contested, reversed or reordered. Claims to 'origin'group status can be established by diverse means. Most commonly, these include oral histories recounting ancestral connections to the land, the possession of sacred artefacts connected to the ancestral past, and the presence of symbolic structures such as sacred houses or particular sites including ancestral burial groups and settlements of origin. Viewed in this light, the 'resurgence of custom' must be understood as part of a process of reaffirming ancestral connections to land and renegotiating relations of precedence following years of war and displacement, policies of resettlement and relocation, and restrictions on movement and cultural practice.

This chapter describes how claims to land and relations of precedence are currently being renegotiated in a predominantly Naueti-speaking locality in the south-eastern district of Viqueque. In particular, it explores discourses of origins and precedence from the perspective of one particular house-based group from the village of Babulo as it seeks to reassert its authority over subsidiary and inmigrant groups within a defined territory.

\section{Background to Suco Babulo}

The village (suco) of Babulo is located in Uatolari subdistrict, Viqueque district, on the south-eastern coast of Timor-Leste. The suco has a total population of 4136 (Direcção Nacional de Estatística 2004), the majority of whom are of the Naueti ethno-linguistic group. ${ }^{2}$ A minority of inhabitants of Babulo are of Makassae origin and some individuals and families are of mixed ethno-linguistic descent. The majority of the population are subsistence farmers. Agriculture is based mainly on the swidden cultivation of maize, cassava, legumes and root crops. Irrigated rice is cultivated in the lowland areas close to the Bee Bui River and dry land (rain-fed) rice is also cultivated in the upland areas. Coconut and candlenut plantations provide many families and individuals with an important cash income. Hunting and fishing are also part of local subsistence strategies. While a limited number of families possess livestock such as water-buffalo (karau-Timor) and cows (karau vaca), many keep pigs, goats and chickens. Livestock is generally considered to be a valuable household asset and holds an important role in patterns of reciprocal exchange, which are at the heart of rural social relations.

2 Alternative spellings: Nauheti, Nauhete and Nauoti. According to census statistics (Direcção Nacional de Estatística 2004), the total number of Naueti speakers in Timor-Leste (over six years of age) is 11 361, of which 9832 reside in Viqueque district. 
Prior to the Indonesian invasion, the people of Babulo lived in dispersed upland settlements or baha. ${ }^{3}$ It was common for these settlements to comprise groups of agnatically related males, their in-married spouses and children. As a result of Indonesian strategies of control, the majority of the population is now settled along main roads or the administrative-post buildings in Uatolari Leten. Since independence, however, there has been a gradual trend towards re-establishing pre-1975 upland settlements. In particular, the older members of the community have chosen to return to these settlements while a younger generation continues to live in Indonesian-period villages. The choice to remain is often dictated by considerations regarding access to services such as education and health care. ${ }^{4}$ Many people also maintain simple temporary shelters in their swidden gardens where they might stay during planting or harvesting season.

Administratively, Babulo is divided into eight hamlets called aldeia: Beli, Darlari, Aha Bu'u, Kotanisi, Roma, Liasidi, Abadere and Asamuta. All but one of these hamlets were established and named during the Portuguese period, and little was done during the Indonesian occupation or since independence to alter these administrative units other than change their name from povação (Portuguese) to kampung (Indonesian) and, most recently, to aldeia (Portuguese). ${ }^{5}$

The Portuguese authorities relied heavily on pre-existing social structures and hierarchies for territorial control, labour recruitment and revenue extraction. In Babulo, each hamlet continues to correspond broadly to a descent group along with their affines and dependants, sharing common ancestors and centred on a common uma luli (sacred house). Each descent group is subdivided into a number of lineages and sub-lineages (uma kain), each of which has its own 'branch' or subsidiary cult house. In the past, these subgroups formed the core of baha settlements and each subsidiary cult house was associated with a specific function and role within the ritual and social organisation of the broader descent group. Members of each branch of a common descent group are typically classified as kaka (older) and wari (younger) in relation to one another. ${ }^{6}$ The members of 'older' houses are considered to be more closely related to the common ancestors of the group and therefore have authority over 'younger'

\footnotetext{
3 In Naueti, baha may mean both mountain and settlement.

4 Other considerations include the investment made in housing during the Indonesian period.

5 The aldeia of Roma was established after independence. The people of Roma are predominantly Makassae speakers.

6 Three broad social subcategories are found in Babulo and across Naueti-speaking communities. These are liurai, reinu and ata. The distinction between liurai and reino is similar to that of wari and kaka. Reinu (sometimes povo or people) groups are subordinate houses of each lineage or sub-lineage within a descent group. Ata (Naueti: slaves) groups are the lowest social category whose ancestors were former slaves or war captives. Intermarriage between these groups was traditionally forbidden.
} 
houses. The senior male members of the 'eldest' house of each descent group are often referred to as $\mathrm{Na}^{\prime} \mathrm{i}$ (Tetun: master) or Bu Dato (Grandfather Lord), and are considered to be the direct descendants of the groups' ancestors. ${ }^{7}$

Complex dynamics of kinship, marriage and long-term alliance bind the principal descent groups around which the administrative units of aldeia are structured. ${ }^{8}$ However, it is unclear how long these groups have considered themselves to form part of a larger unit such as a suco. The village headman (liurai or chefe suco) of Babulo is traditionally 'selected' from the hamlets of Aha Bu'u and Kotanisi. ${ }^{9}$ These hamlets represent two lineages of the same descent group, originally called Burmeta. ${ }^{10}$ Informants suggest that the ancestors of the Burmeta emerged as political leaders in the area by threat of force and through strategic marriage alliances with local house-based descent groups. ${ }^{11}$

Despite a history of considerable in-migration during the late colonial period, followed by massive displacement and forced relocation of the population from the upland areas surrounding Matebian Mountain during the Indonesian occupation, aldeia and suco composition based on group membership has remained unchanged. As a consequence, approximately 50 per cent of the population currently residing in Babulo is originally from the neighbouring suco of Afaloicai and remains under the jurisdiction of their own hamlet and village chiefs. Although many of the people from Afaloicai have long been settled in the area, they continue to maintain physical links with their ancestral lands and make a clear distinction when speaking about their place of residence and place of origin. By the same token, while there is a long history of social interaction between the people of Afaloicai and Babulo, in particular through marriage alliances, many local groups continue to view people from Afaloicai as in-migrants with limited and sometimes temporary rights to access land and other natural resources. This apparent administrative anomaly is not

\footnotetext{
7 Hamlet chiefs are usually drawn from the members of the 'eldest' house - usually, the son (or nephew) of one of the senior male members.

8 Traditionally, members of each descent group are exogamous and must seek marriage with members of other groups. Marriage establishes the basis for reciprocal relations between groups who become wifegivers (uma ana) and wife-takers (oa sae) in relation to one another. In practice, it seems that marriages do occur between members of lineages and sub-lineages although these are often frowned on. Members of liurai lineages may not marry their subordinates and must buka liurai (seek marriage with other liurai groups).

9 While 'democratic' elections for the positions of chefe suco and chefe aldeia were held in 2004-05, as in other parts of Timor-Leste, in Babulo, only members of the recognised lineage were permitted to nominate themselves as candidates. Local informants state that candidates had to be members of the liurai family of Aha $\mathrm{Bu}^{\prime} \mathrm{u}$ or Kotanisi (descendants of Burmeta), in accordance with the ancient juramento that existed between the Burmeta and Darlari.

10 The Darlari refer to the people of Aha Bu'u and Kotanisi as Burmeta. The people of Aha Bu'u and Kotanisi acknowledge a common ancestor called Boru Buti. According to one informant, the name Burmeta was used to refer to warriors who came from Matebian Mountain. In Makassae, Matebian Mountain is also called Bere Meta-Bere: (Big) Meta (Black).

11 This interpretation of events reflects Fox's variation on the theme of the stranger king whereby the powerful 'outsiders' are installed 'inside' as local chiefs through processes of incorporation (Fox 1995).
} 
uncommon in Timor-Leste. In the case of Babulo, it reflects the way in which the administrative units of hamlet and village were established and fixed during the Portuguese period. And it calls attention to how attachments to land are linked to local discourses of origin and precedence that underpin these colonial structures.

\section{The Darlari Domain}

In Babulo, hamlet and village administrative units, and the concomitant offices

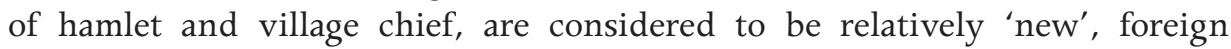
structures, associated with 'external' relations between the community and outsiders - in particular, the state. The underlying community of house-based groups, on the other hand, forms 'old', autochthonous structures dealing with the 'internal' management of collective social and ritual relations within and between house-based groups.

Within the traditional community, members recognise the authority of specific 'origin groups' over defined territories or domains. Origin-group status is predicated on interrelated notions of ancestry, attachment to place, histories of migration and settlement and networks of alliance. In Babulo, one such group is composed of the 'eldest' houses, or senior lineages, of the hamlets of Beli and Darlari. ${ }^{12}$ These groups represent the lineages of two brothers who were the direct descendants of the mythical founders of an ancient kingdom called Bubulu. $^{13}$

According to local tete bo'ona (Naueti, lit.: oldest stories), the sibling ancestors of Beli and Darlari lived together near Baha Liurai, the ritual centre of their land and burial site of their ancestors. Both were entrusted with the custodianship of their ancestors' sacred land (rea luli) and sacra (sasan luli). One season, when the time came for them to harvest their rice fields, the brothers agreed that one of them would go and harvest their portion of rice while the other guarded the sacred land and sacra at Baha Liurai. ${ }^{14}$ The elder brother (Beli) went to the fields first, while the younger (Darlari) waited silently for his brother to return. When the elder brother arrived at the fields, he saw that his harvest was plentiful and

12 The origin names of the descent groups that comprise the hamlets of Beli and Darlari are deemed sacred and may not be spoken. In everyday exchange and even during communal rituals, these groups are referred to using their hamlet denominations. The principal cult houses of Darlari are commonly referred to as the Um Buti (white house) and Um Ita (black house). Beli, on the other hand, have a single principal cult house, referred to simply as Um Luli (sacred house). The 'real' names of these houses are linked to the descent-group genealogies seldom disclosed to outsiders.

13 In Darlari origin narratives, Babulu is presented as encompassing 'all the land over which the sun reigns'. The narrative of ancestral origin focuses on the exploits of the Mane Hitu (seven brothers), the offspring of a human female and a crocodile male, who reached Timor Island from the sea and took possession of the land.

14 These rice fields are called Lia Kakeu and continue to be farmed by Darlari. 
he was happy. Once he had finished harvesting, he returned to Baha Liurai so that the younger brother could go and attend to his crop. While the younger brother was away, however, the elder brother did not keep silent vigil over the sacred land and sacra but started celebrating the success of his harvest with singing, drum playing and dancing. In the meantime, the younger brother reached the rice fields but he could not find any of his own crops. When he returned to Baha Liurai and found his elder brother revelling, he flew into a fit of rage and grabbed the drums and other instruments, breaking them. ${ }^{15}$

By neglecting his duties to the ancestors, the elder brother had caused the younger brother's harvest to disappear. The brothers fought and decided to separate. The elder brother was banished from the sacred land of his ancestors and had to settle on land belonging to his wife-givers (uma ana).

The transgression of the elder brother and his exile to the territory of his wifegivers serve to justify the reversal of common concepts of authority based on genealogical precedence. As a consequence of the actions of their ancestors, the liurai lineage of Beli forfeited their right to claim status as heirs to the domain of their mythical founder-settler ancestors. This privilege was bestowed and retained uniquely by the male-line descendants of the younger (Darlari) brother who remained at Baha Liurai. Members of the senior Beli and Darlari houses continue to acknowledge their sibling status through the use of the terms kaka and wari (elder and younger), while other groups living on their ancestral lands related through marriage or long-term alliance refer to them collectively as Ina Ama Beli Darlari (Mother Father, Beli Darlari). ${ }^{16}$ In recognition of its senior status, the liurai lineage of Darlari is accorded the title of rea bu' $u$ or 'lord of the land' ${ }^{17}$ This is also expressed as rea mumu, rea uato (rod of the land, rock of the land) in formal ritual speech. Today, the authority of the 'lord of the land' is embodied in the headman (Bu Dato) and former chefe povação of Darlari. He shares this responsibility with two other senior Darlari members, one of whom 'sits and watches' over the ancestral sacra placed in the main Darlari cult houses, the um buti and um ita (white house and black house).

15 To this day, it is generally forbidden to play music or dance at Baha Liurai; however, exceptions are sometimes made for young children and when the elders wish to listen to the radio.

16 Darlari and Beli elders presented two versions of this narrative to the author on separate occasions. Both original narratives conform to this summary. They differ only with regards to the significance of objects that the elder (Beli) brother took with him to his exile. In the Darlari version of events, the elder brother left with no ancestral sacra. In the Beli version, the elder brother took with him the drums and instruments that were the cause of his exile. With time, these objects have become sacralised in their own right.

17 The term in $b u^{\prime} u(n)$ in Naueti literally means 'lord' or 'owner'. It may, however, also be translated as 'grandfather', 'ancestor' and sometimes 'spirit' — understood as a non-human entity. Rea bu'u = owner of the land or lord of the land; uai mata $b u^{\prime} u=$ owner of the spring; rea bu' $u=$ owner of the land; kai bu' $u=$ owner of the forest, and so on. 
As 'lord of the land', the Darlari elders are the chief stewards of their ancestral lands. ${ }^{18}$ Darlari elders claim that the 'original' boundaries of their domain extend far beyond current aldeia or even suco boundaries. They argue that these boundaries were established long ago (before the arrival of the Portuguese), often as a result of conflict with neighbouring groups and agreed upon by means of sacred oaths, or juramento. ${ }^{19}$ However, they also recognise that throughout the colonial period their land was slowly encroached upon as the colonial authorities extended their control over the territory, often favouring powerful neighbouring kingdoms.

To the north and north-east of their domain, the Darlari identify two groups referred to as ki butana/ki itana (people of the white children/people of the black children); these correspond roughly with the principal descent groups that make up the aldeia of Liasidi ( $k i$ itana) and Balabaciba, Vessoru ( $k i$ butana), which are related to the Darlari through marriage. To the northwest, Darlari recognise the kingdom of Builo against whom their ancestors fought a fierce battle to establish a border. ${ }^{20}$ To the east and west of Darlari (and Beli) lands, along the coastal plain, the descendants of an in-migrant group from Luca now dominate. Darlari claim, however, that in the past their authority extended as far as present-day Lughasa, close to the border with Viqueque subdistrict. ${ }^{21}$

While the Darlari elders continue to contest the boundaries of their domain in private, they are reluctant to make these claims public, as they believe this might stir up unnecessary and perhaps even violent conflict with neighbouring groups. To legitimise their claims, they refer to ancestral histories and name specific sites where the ancestors are believed to have landed, settled, farmed, fought, died and were buried. These sites are marked by physical features such as rocks, springs and specific areas of old-growth forest as well as symbolic structures such as stone altars, ancestral graves and particular uma luli (sacred houses) where ancestral sacra are stored. The memory of these histories and the significance of these sites are preserved through local tete bo'ona (histories) and reinforced through specific rituals associated with place. Many of these sites are considered to be luli (sacred) and access is restricted, or must be mediated through communication with the ancestors and $b u^{\prime} u$ (spirits) that guard them.

\footnotetext{
18 In the past (and perhaps in the present), 'lord of the land' status also gave rights to demand labour and services from other kin-group members.

19 These juramento took the form of blood-oaths and are considered to be luli (sacred) - broken on pain of death or some other form of ancestral retribution.

20 Builo is a mountain located within the ancestral lands of the king dom of Ossurua, which is a predominantly Makassae-speaking area. The author visited this area and heard similar stories of conflict with a kingdom to the east (Babulo). They also confirmed histories of the 'passage' of representatives from Luca on their way to the Uatolari plains.

21 Of interest is the distant connection with Naueti speakers in the Beasu area of Viqueque. This group appears to me an anomaly in the spatial distribution of Naueti language (cf. Hicks 2007:245). Informants from Babulo, however, claim that these are descended from war captives who were taken to the coastal area to be 'traded' for firearms.
} 


\section{Histories of Incorporation and Accommodation}

Ancestral itineraries and histories serve not only to reinforce the emplaced nature of claims to authority, but also to reaffirm the order of arrival and settlement of various descent groups living within these territories. At the same time, these narratives provide a guide to understanding the dynamics and processes whereby subsidiary groups were formed and in-migrant groups were incorporated into the social order (Lewis 1996). Darlari elders offer two interrelated and recursive narratives to determine precedence and explain the nature of social relations within their territory. One is concerned with the history of land allocation and the other explains the delegation of tasks or duties to subsidiary houses and in-migrant groups.

The Darlari elders represent the highest ritual or spiritual authority within a domain, which incorporates numerous house-based descent groups. Although Darlari elders claim that in the past their ancestors held both ritual and jural power over the territory and people of their domain, they acknowledge that at some stage in their history, their forefathers began to 'retreat into darkness', delegating specific tasks to members of other house-based groups. Ostensibly, the elders state that this 'retreat into darkness' was a conscious decision in order to keep the secrets of their land from 'outsiders' - in particular, the colonial authorities (and the Catholic Church). ${ }^{22}$ However, they also acknowledge that the delegation of tasks to other groups was a means of appeasing subsidiary lineage houses and in-migrant groups that represented a potential threat to their authority. Similarly, the allocation of land as part of 'traditional' contracts including juramento (solemn oaths) or intermarriage was (and continues to be) used as a means of incorporating in-migrant groups into local social and political structures.

Today, the Darlari elders claim that within their domain there remains no 'unused' or 'unallocated' land. They state that long ago their land was divided into five areas corresponding to the five main 'houses' of the Darlari descent group. ${ }^{23}$ Members of these houses gain access to land by virtue of their genealogical relation to the common Darlari founder-settler ancestors. To continue to benefit from the land and natural resources, members of these houses are expected to

\footnotetext{
22 The Makaer (spokesperson) for the senior Darlari house explained that their forefathers delegated these tasks to other houses because they wanted to be 'above' the everyday matters of managing their 'kingdom'. Rather than a sign of weakness or loss of power, this 'retreat' into darkness becomes a source of strength. In the context of independence - having resisted 'outsiders' and maintained their identity — this has become a means to legitimise attempts of the Darlari elders to reimpose their authority.

23 Darlari informants state that these territorial divisions are well known and marked by physical features such as streams, hills and rocks. Nevertheless, these demarcations do not represent five distinct units but rather a patchwork of holdings scattered across the domain, reflecting traditional farming practices based on shifting cultivation.
} 
fulfil their ritual and social obligations to members of superior houses and the ancestors. Failure to do so is believed to incur the wrath or displeasure of the ancestors and might result in some form of misfortune, illness or death. ${ }^{24}$

Darlari elders also state that their ancestors delegated the task to monitor the use of land and natural resources - lai bosa, lai wai (Naueti: guard the fields, guard the water) - to one of the sub-lineage houses (um kain) of Darlari called the uma kabo. Later, according to local histories, the main representative of the uma kabo, the Kabo Rai, asked the Bu Dato to grant his house a token of office so that those under its jurisdiction would have something to 'believe in' or 'fear' ${ }^{25}$ As a result, the Darlari elders state that a Makaer Luli (keeper of the sacra), a ritual specialist, was appointed to assist the Kabo Rai in his task.

The Kabo Rai's function is practical: to monitor land use and access to natural resources, including the application of seasonal prohibitions on the harvesting of various products, collecting tributes for collective ceremonies and/or exacting fines for the infringement of prohibitions. ${ }^{26}$ They are assisted in these practical tasks by representatives of two other subsidiary houses of Darlari: Asu Rati Reino and Asu Rati Liurai. ${ }^{27}$ The role of the Makaer Luli on the other hand is more spiritual: presiding over collective rituals, acting as an intermediary with the spirit world, and 'watching over' the sacra held in the uma luli at Burlalu.

One of the principal in-migrant groups comprises the descendants of Burmeta. Today, this group is divided into two lineages corresponding to the aldeia of Aha Bu'u and the other Kotanisi. ${ }^{28}$ Darlari describe the descendants of Burmeta as asuwain (warriors) and claim they arrived in the area some eight generations ago. The origins of the Burmeta are contested. Some claim they are liurai who came from the east of Matebian Mountain in search of land while others claim they were banished from their ancestral lands. Darlari elders claim that the Burmeta stopped and camped on land close to Baha Liurai on their way to offer vassalage to the kingdom of Luca. Rather than let these warriors join forces with their strong neighbour, the Darlari ancestors offered the Burmeta some land on which to settle and in exchange asked them to protect the borders of their domain.

\footnotetext{
24 The obligation to participate in regular communal ritual is essential to the production and reproduction of discourses of origin on which the social organisation of the community is structured.

25 Although local informants insist this is an autochthonous title, kabu appears to be derived from the Portuguese military rank cabo. Kabo Rai is a Tetun term.

26 Although most claimed to be children at the time, a number of older informants remembered the practice of collecting tribute for the yearly rice harvest. Today, the Kabo Rai continues to inform the 'lord of the land' of activities affecting land and natural resources. For example, the author was present when the Kabo Rai informed the Bu Dato that a local in-migrant family from Afaloicai had asked to build a permanent, cementblock house on their land. In order to do so, the family was to present a large pig at the communal rice-harvest ceremony.

27 It seems likely that the term Asu Rati is a corruption of the Portuguese term ajudante, or assistant.

28 Sometimes Kotanisi is referred to by its Naueti name, Kaidu.
} 
To the Burmeta, the Darlari ancestors gave the title of ana bo'ona, ana tadana (the eldest and wisest son). This group was designated the task to lai reinu, lai rea (guard the people, guard the land), to rule over the people and protect the borders of the domain. More specifically, this group became known as the gatekeepers (ita mata, kai hene: door and gate) between the traditional 'inner' community and 'outsiders' - in particular, the colonial authorities.

The Portuguese granted the title of Tenente Coronel to the head of the Burmeta clan, and traditionally, chefe suco (village headmen) are chosen from this group. Members of this group stress that they were granted authority to ukun (Tetun: rule or govern) over the people of Babulo suco when they received a rota (a staff often used as a symbol of office) from Viqueque. ${ }^{29}$ They describe their role in terms of local governance in relation to the state. In the past, this entailed specific duties and responsibilities regarding the settlement of local disputes, the collection of taxes (for the colonial authorities) and the recruitment of labour for colonial or state projects. Today, they continue to consider the role of the chefe do suco as an intermediary between the local community and the state, or other 'external' parties such as national or international non-governmental organisations.

Often described as the right and left hands of the Bu Dato, the descendants of the Burmeta and the offices of the Kabo Rai and Makaer Luli have come to represent jural and ritual power respectively within the Darlari domain. ${ }^{30}$ The delegation of authority to these groups and dualistic structures of authority created in the process reflect common patterns and themes observed throughout Austronesian societies (Fox and Sather 1996). Darlari elders are keen to point out that the power of these groups is always subordinate to the authority of the rea mumu, rea uato (lord of the land). ${ }^{31}$

29 During the eighteenth and nineteenth centuries, the Portuguese colonial authorities granted military titles to local potentates. The rank of tenente coronel was usually superseded by the dom (de Menezes 2006). On the coastal plain of Uatolari, the rulers of the kingdom of Vessoru/Uaitame were given the rank of dom. Local informants from Darlari, however, claim that this dom was in fact a descendant of the Luca Dom who had been sent to broker peace between Babulo and Builo. The history of the kingdom of Luca is fertile ground for further research.

30 Today, the Uma Buti and Uma Ita of the Darlari represent the centres of ritual power but are politically weak. They are often juxtaposed with the um luli of Bur (Boru) Lalu and Bor(u)laisoba, which are now politically powerful but ritually weak. See Trinidade (2007) for more details on dualist power structures.

31 As proof of their seniority, the Darlari elders explain how they gave the Burmeta and the Kabu Rai/Makaerluli a number of sacred objects believed to have belonged to the Beli/Darlari ancestors. The objects given to the Burmeta are stored in an uma luli at a place called Burosoba. To ensure that the political leaders of Burmeta did not try to usurp the ritual authority of the Bu Dato by trying to handle and harness the power of these sacred objects, a second Makaerluli was appointed to guard the objects and control access to this house. The sacred objects given to the Kabu Rai and the Makaerluli on the other hand were placed in an uma luli built at Burlalu. This site was chosen as it was believed to have been the first place the founding ancestors settled on their arrival in the area from the sea. 
Another in-migrant group closely associated with the Burmeta lineages now makes up the majority of people of the aldeia of Roma. Many Darlari and Aha $\mathrm{Bu}^{\prime} \mathrm{u}$ informants refer to this group as 'the aldeia without land'. The aldeia of Roma was established after independence. The members of the Roma grouplocally known as Laka Roma - represent a group of ata (slaves) originally from Quelicai who traditionally served the liurai lineages of Aha Bu'u and Kotanisi. According to one history of the origins of this group, the Laka Roma served a liurai of the Burmeta descent group who lived in exile near Quelicai. When the liurai's family eventually asked him to return to Babulu and become the chief liurai, he agreed on condition that he could bring 'his people', who were 'stuck' to him like the 'seeds of a long grass' called laka roma in Makassae.

The Laka Roma were not granted specific areas of land on which to farm or settle by the Darlari 'lord of the land', but were servants of the chiefly houses of Aha Bu'u, Kotanisi and Darlari. In the past, one of the main tasks of the Laka Roma was to watch over the buffalo of their masters. Local informants state that in time the Laka Roma started farming land near the animal enclosures or land where they regularly took the animals to pasture. Many members of this group now claim these areas of land as their own, based on long-term occupancy.

The third, most recent and largest group of in-migrants was originally from the neighbouring suco of Afaloicai. Locally, people broadly distinguish between three movements of people from Afaloicai to Babulo. The first group, mainly from the hamlets of Buibela and Lena, arrived sometime in the 1930s in search of land. The second group came during the post-war period, at first seasonally, to work in the rice fields that were being 'developed' on the Uatolari coastal plain, and later settled more permanently in the area. The third group was forcibly displaced from their villages of origin as a result of the Indonesian invasion and 'relocated' following the 'surrender' of civilians from the resistance stronghold at Matebian Mountain in 1979. The way in-migrants from Afaloicai gained access to land on which to farm and settle depended on the circumstances of their arrival and the level of engagement with the Darlari 'origin group', their kin and affines. In-migrants from Afaloicai, however, do not appear to have been incorporated into the local social order in the same way as the descendants of the Burmeta or the Roma. They were not 'installed on the inside' (cf. Fox 1995) by taking up a specific role or rank within the social hierarchy of the Darlari domain. ${ }^{32}$ They remained organised according to their own house-based descent groups, hierarchically ranked and ordered in accordance with their own

\footnotetext{
32 One could speculate numerous reasons why the people of Afaloicai were not fully integrated into the local social order-for example: timing, as migration occurred after wars of pacification. The local power of the Darlari 'lord of the land' was waning and the Portuguese were firmly in control and installed in the posto at Uatolari. It is possible that an alliance was made between the rulers of Afaloicai and the descendants of the Burmenta. The leadership of these ruling groups was later embroiled in the 1959 rebellion against the Portuguese.
} 
histories of origin and precedence. Their residence on Darlari lands is often viewed as temporary, and in the context of communal rituals the people of Afaloicai are often referred to as 'the people who use the land for farming and gardening'.

Some suggest that in-migration in the 1930s was triggered by constant conflict between petty-kings around the area of Matebian, which led to the fragmentation of Afaloicai into three distinct suco (Afaloicai-Baguia, AfaloicaiUatolari and Afaloicai-Uatocarabau) and forced some people to leave their land. ${ }^{33}$ Others believe that the newly appointed chefe suco of Afaloicai-Uatolari, who was not of the 'ruling' houses of Afaloicai, wanted to move closer to the Portuguese colonial authorities at the posto (subdistrict centre) that had recently transferred from Tualo on the coast to Uato-Lari near Babulo Mountain. Still other informants, such as the current chefe suco of Afaloicai, state that increased population pressure, poor soils and difficult farming conditions in the rocky foothills of Matebian all contributed to the decision to migrate towards Babulo and other locations near the coast. ${ }^{34}$

Local informants recall that Liurai Gregorio, originally from the hamlet of Lena, arrived some time before the arrival of the Japanese. The elders of aldeia Darlari claim that Liurai Gregorio and his people arrived with some fanfareaccompanied by drums and whistles - and set up camp on rea luli (sacred land) near Baha Liurai. However, it was not long before they started falling ill because they had not respected the prohibitions associated with this land. As a result, Liurai Gregorio approached the Darlari elders and asked them for some land on which to settle and farm. A marriage alliance was established between the two groups and as a son-in-law, Liurai Gregorio and his people were offered some land to farm and settle. They settled at a place called Tua Rae Laleo (shelter of palm wine leaves) and were also given land on which to farm at a number of sites around present-day Uatolari Leten and Kampung Baru.

Access to this land is mediated and managed within the framework oa-sae/uma ana relations (marriage relations). Throughout Timor-Leste, marriage alliances establish a set of reciprocal social and moral obligations between families and groups. Through marriage into the Darlari 'origin group', Liurai Gregorio and his followers were integrated into the broader community by entering into local

33 Informants from Babulo and Afaloicai also suggest that the Portuguese colonial authorities and their allies from the kingdom of Luca purposefully divided the kingdom of Afaloicai in order to weaken it. The border between the posto of Afaloicai Baguia and Afaloicao Uatolari split the main uma luli of Buibela/Lena in two (Source: chefe suco Afaloicai; also see Gunter 2008).

34 Local informants also claim that during this prewar period, people from Afaloicai began to settle beyond the boundaries of suco Babulo. Some state that the liurai (chefe do suco) of Uaitame, Dom Umberto, and his successor, Gaspar from Sana, invited people from Afaloicai to come to work on their land around present-day Darabai and west of the Bee Bui River. Much of this land has been the subject of an ongoing dispute between individuals and groups from Afaloicai and the suco of Makadiki and Matahoi. 
networks of alliance and exchange. As oa-sae (wife-takers), Gregorio and his followers were expected to contribute goods and services to their Darlari uma ana (wife-givers). In exchange, they were allocated specific plots of land on which they were permitted to farm and build their houses. Over time, other marriage alliances were formed between families from Afaloicai and the local houses of Babulo in general and Darlari in particular. ${ }^{35}$ Darlari elders insist, however, that according to the original juramento (oath or agreement) with Liurai Gregorio, land was not (and could not) be transferred outright but rather remained under the ultimate control of the 'lord of the land'.

From the 1950s onwards, colonial policies aimed at 'developing' local agriculture led first to seasonal and later to more permanent migration from the upland communities around Matebian, including Afaloicai, to the lowlands. Local informants state that during the 1950s and 1960s, chefe suco and chefe povação from the entire subdistrict of Uatolari were ordered to organise work groups to 'open up' the coastal plain for rice cultivation. For many of those who arrived in Babulo during the post-war period, access to land was no longer necessarily mediated through marriage into local groups but rather through their relationship with other family members from Afaloicai previously settled in suco Babulo and neighbouring Vessoru-Uaitame. Many in-migrants during this period set up temporary housing while they worked on land allocated to them by the local authorities.

\section{War, Displacement and Disruption of the Social Order}

The capacity of the Darlari 'lord of the land' to negotiate or determine land allocation to in-migrants was severely diminished as a result of the Indonesian invasion and its aftermath. Indonesian troops are reported to have advanced towards Uatolari subdistrict from the port at Beasu in mid to late 1976. Local informants describe both erratic and systematic patterns of displacement between 1976 and 1979. Some informants report taking part in group movements or 'evacuations' organised by local Fretilin (Frente Revolucionária de Timor-Leste Independente) delegates to specific sites; in other cases, individuals and families state that they made their way over a period of two to three years towards the Matebian Range, either on their own or in groups with their chefe aldeia and

35 For example, land at place called Kai Oris was given to the oasae (wife-takers) from Afaloicai of the house of the Kabo Rea. 
chefe suco. Sometimes people sheltered for a few days in a particular area while at other times they stayed for a few months, often building temporary housing and finding time to plant crops. ${ }^{36}$

Informants from aldeia Darlari describe how the area 'emptied'. People left even the more remote settlements, fleeing the Indonesian troops, and looking for shelter from the aerial bombardments. Most informants described reaching Matebian in mid to late 1979 and staying there until the Fretilin leadership 'ordered' the 'surrender' of the civilian population. ${ }^{37}$ Conditions on Matebian Mountain were traumatic. Informants describe how they lived in fear of the aerial bombardments, taking shifts to sleep in cramped conditions with little food or water. Many informants attribute their survival during this period to the fact that the Darlari elders (and their sibling, Beli) did not abandon their ancestral sacra but carried them with them to Matebian. ${ }^{38}$

The 'surrender' and return of the civilian population to areas under the control of the Indonesian military began in late November 1979. As elsewhere in East Timor, the inhabitants of suco Babulo were ordered to report to internment and resettlement camps while the troops conducted military mop-up operations in the area (CAVR 2005). The main internment camp in Uatolari subdistrict was established at the old posto at Uatolari Leten. People from all six suco of Uatolari, as well as the subdistricts of Baguia and Quelicai, were 'contained' within a restricted area around the subdistrict centre. For the first few months, the Indonesian military and East Timorese collaborators surrounded the encampment and people were not permitted to leave unless accompanied by an East Timorese or Indonesian guard. Informants describe how during this time people had little or no shelter and they had to sleep, eat, wash and go to the toilet within the guarded perimeter. Food was scarce and they had restricted (and sometimes no) access to fields and gardens beyond a specified distance.

In the early 1980s the Indonesian military began relocating the population. Most of the population residing in the suco prior to the invasion was relocated from isolated upland settlements to linear settlements along the main road

36 Most informants claim that political violence within suco Babulo was contained as a result 'traditional' alliances and oaths. The perpetrators of violence were often described as 'outsiders' from groups who were displaced to Babulo as a result of the internal armed conflict between UDT (União Democrática Timorense, the Timorese Democratic Union) and Fretilin, and the Indonesian invasion. The chefe suco of Babulo was (and is) closely related to the liurai families of Afaloicai. In fact, descendants of the Burmeta refer to the rulers from Buibela/Lena in Afaloicai as their 'younger brother'. During the Indonesian occupation, certain 'ruling' house-based groups from Afaloicai rose to political and economic prominence at local and national levels. Gunter (2007) has described the way in which local groups have become trapped in a vicious cycle of 'victim and victimisation' based on changing political fortunes.

37 Generally, this is dated about 23 November 1976.

38 Both Beli and Darlari claim that few of their own people were killed during this period; however, this is generally refers to people who had died as a result of bombing or later executions, rather than deaths due to illness and hunger. 
networks. Some informants claim that East Timorese who collaborated with the Indonesians had considerable influence over where people could be relocated. ${ }^{39}$ Within the Darlari domain, some degree of homogeneity was retained as members of the same house-based groups were relocated together. Today, members of the principal houses of Darlari, Beli, Aha Bu'u and Kotanisi state that the time the chefe do suco of Babulo consulted with the Darlari and Beli elders as to where groups should be relocated. ${ }^{40}$ The majority of the population, however, appears to have remained close the posto at Uatolari Leten or moved to the new settlement of Kampung Baru. Continued restrictions on movement during the 1980s and early 1990s meant that fields and gardens in more remote upland locations remained 'off limits'. Some informants claim that these restrictions were 'self-imposed' - as people feared attacks by the armed resistance, or of being suspected of collaborating with Falintil.

Darlari elders claim that increased population pressure and limited access to land meant that people just went ahead and farmed whatever land was available in order to survive, circumventing any 'traditional' principles and processes of land allocation. The destruction of um luli structures and restrictions on movement prevented regular ritual communication with the ancestors and inhibited ceremonial life around which the social order of the Darlari domain was structured. Nevertheless, informants claim that the relocation of the population into more densely populated clusters according to aldeia membership helped to maintain a degree of continuity. For example, the Darlari elders continued to perform yearly harvest rituals, albeit in a 'simplified' form. They constructed small traditional houses in which to store the ancestral sacra and people continued to seek their advice and assistance.

\section{Knowledge and the Sacred}

The authority of Darlari elders as 'origin group' representatives rests in their position as legitimate heirs of the founder-ancestors and is sustained by their intimate knowledge of their land and its history. Local informants claim that only the Darlari elders have the full knowledge from 'trunk to tip' (la'a-na, raena) of the arrival and settlement of the founding ancestors, the establishment

\footnotetext{
39 Some (but not all) of the East Timorese collaborators in Uatolari had previously been involved - directly or indirectly - in the anti-colonial uprising of 1959; others had suffered at the hands of Fretilin during the internal conflict and saw their opportunity for revenge.

40 For example, although Beli and Darlari were not permitted to return to their upland settlements, they were relocated to Aliambata. Darlari elders argue that this site was chosen as it was close to a number of important common luli sites, including the offshore gas seep located some $100 \mathrm{~m}$ from the settlement. The chefe do suco from Aha Bu'u and his family also relocated to Aliambata. Some suggest that this was in order to control access to the Aliambata gas seep and ensure that 'outsiders' did not try to exploit these resources without consultation.
} 
of local houses and the eventual arrival of in-migrant groups. They know the history of conflict, past treaties, alliances and juramento (oaths) within and between local and neighbouring groups. They know the history of land use, the boundaries of their domain and the way land was allocated to local and in-migrant houses. But most importantly, they know the names of the various spirit and ancestral guardians that control access to the forest, fields and water sources of their domain. Knowledge of this ancient and therefore sacred time is not accessible to all members of the community.

Knowledge is considered to form part of the legacy of the ancestors and is usually passed on from one generation to the next at the last possible moment. Even if the person chosen to inherit this knowledge is not considered to be bright or eloquent, people believe that they will be 'possessed' or 'filled' by the knowledge they receive. Darlari elders describe the knowledge bestowed on them by their ancestors as both a privilege and a burden. Only the elders 'may speak' and therefore pass judgment on what is considered to be luli and what is not. ${ }^{41}$ Through this knowledge, they have become the privileged intermediaries between the 'light' and 'open' world of the living and the 'dark', 'hidden' world of the ancestors. This knowledge also means, however, that they are bound to 'service' regardless of whether or not they receive any support-material or otherwise-from the community.

Darlari elders are keen to point out that they do not worship uato no kai (rock and tree) but rather they insist that, even prior to the arrival of the first Catholic missionaries, they believed in a creator-god entity called Wula' Lara (Moon Sun). ${ }^{42}$ According to the elders, Wula' Lara created the world and then placed certain people on earth to 'control' (ei) and 'tame' (masi) the land. Before the arrival of these 'chosen' people, the inhabitants of the earth lived like 'people with no rules and regulations' (ikutame, garteme). As the chosen people took control of the land, they established behavioural norms and practices that formed the basis of the social and moral order. As descendants of these 'chosen' people, the Darlari elders have a duty to ensure that the social and moral order is maintained through the continued application of these norms and practices.

Behavioural norms and practices have developed over time and as such they have also been shaped by interaction between individuals and groups. With time, some have gathered strength and others have weakened. Often presented as luli (sacred), these norms and practices regulate everyday ritual and social life.

\footnotetext{
41 The term luli has a range of meanings and applications. In Naueti, the term ba'ina is also used to describe what is prohibited or considered to be 'untamed' or out of control. Something that is ba'ina or luli may become masi (tame or sweet) through ritual transformation. The word luli is frequently used to denote all that is sacred but at the same time all that is dangerous or prohibited. There is a direct correlation between time and the sacred (luli) objects; names, places and norms increase in value or potency across multiple generations.

42 Also sometimes spelt Ulu Lara.
} 
The most sacred/dangerous of these norms are those associated with the arrival and settlement of the founding ancestors. In settling the land, the ancestors were responsible for naming the physical landscape: hills, rocks, rivers, streams, springs, forests and fields. They also began to exercise control over nature. They cleared and burned the land to make way for fields and gardens; they used natural resources from the forests to build shelters and provide food and fuel; and they used water from various springs to wash, cook and cleanse themselves. It is believed that, in taking control of the land and its natural resources, the ancestors set the precedent for interaction with the $b u^{\prime} u$ - the original 'owners' or guardians who inhabited the earth. ${ }^{43}$

Among the population currently living on Darlari lands, there continues to be a strong belief, among both young and old, in the existence of an 'unseen' or 'hidden' dimension inhabited by various forms of bu'u. The most powerful bu'u are independent or untamed 'owners' (of the land or natural resources) who can take on human or animal form. In general, it is believed that bu'u have the power to control natural processes and influence the relationship between people and the land. Many believe that failure to respect the luli proscriptions governing interaction with the $b u^{\prime} u$ has negative consequences. It is therefore customary to 'follow in the footsteps' of the ancestors by performing specific rituals, invocations and offerings in order to placate the $b u^{\prime} u$ and gain safe access to the resources they guard.

A number of informants recounted stories of individuals who failed to respect prohibitions associated with specific locations, such as areas of forest or bodies of water, and either became gravely ill or, in some instances, died as a consequence. It is common for people to interpret accidents, illness or some form of personal tragedy as a sign that they, or a member of their family, have somehow done something luli or prohibited. Those who survive or are able to overcome their difficulties are able to do so because they seek to make amends by consulting the elders on how best to placate the angered $b u^{\prime} u$.

Over time, the ancestors themselves have been 'spoken into' the landscape. Numerous places and locations across the Darlari domain where ancestral spirits are believed to congregate are deemed luli. Through their actions and deeds - sometimes involving great personal sacrifice and even death - various named ancestors are remembered for having provided the first harvest, securing the borders of the domain or protecting the land from natural disasters. ${ }^{44}$ The principal of reciprocity underpins the relationship between those living on the

\footnotetext{
43 See Note 13.

44 Part of the Darlari 'origin' narrative that deals with the arrival of the ancestors and the trials and tribulations of the Mane Hitu deals with the personal sacrifice made to secure the 'first' harvest of the founderancestors.
} 
land and the ancestors. The seasons are punctuated with communal and smaller house-based rituals during which invocations and offerings are made to the ancestors to ask for their continued protection and bounty.

Small groups perform one such ritual in their fields just before the corn ripens for harvest. This ceremony, called masi eka rae rea ena (literally: washing the corncob leaves), is performed in order to ask the 'owners' of the field (rea bu'u) to protect their harvest. During this ritual, the corn (eka rae) is transformed from ba'ina (still forbidden and sour) to masi (tamed, allowed to be eaten and sweet). It is believed that rea bu'u have the ability to transform themselves into mice, insects or some type of plant parasite or plague that might destroy the crop. During the course of the ceremony, a number of other ancestral bu'uusually those who first farmed the land-are also invoked. A ritual offering of eggs, rice and some meat is prepared. Part of the food is distributed along the boundaries of the field, some is placed in the centre and the rest is shared among those present. The eggs and meat are first 'distributed' to the ancestors and $b u^{\prime} u{ }^{45}$ An invocation remembering the life or deeds of each is made directly to each ancestor or $b u^{\prime} u$, that they will continue to protect, preserve and provide bounty to the person who farmed the field. Sacrificial meat is offered to the youngest of the Mane Hitu, who sacrificed himself to provide the ancestors with the first harvest; then to the Mak Lihat who is believed to watch over all Darlari lands; followed by the Aman Uma Luli, the founder of the Darlari descent group, and the Mak Sabar, the spirit guardian of the harvest. Final offerings are made to the 'creator-god', Wula' Lara and to the earth, giver of life.

Behavioural norms and practices are not limited to interaction with the land and natural resources but extend to the nature of relations between male and female members of the community, preferred paths of alliance/marriage and social ranking within and between house-based descent groups. Critical to the production and reproduction of these norms and practices are historical narratives and regular ritual communication with the ancestors. Darlari elders lament the fact that today many people living on their land-including members of Darlari houses - do not perform the necessary rituals to ensure the continued fertility of their land and the prosperity of its people. They also claim that many people do not know the history of the land or the correct invocations to be made, and some 'outsiders' continue to invoke ancestors from their places of origin rather than the local emplaced bu'u. According to the elders, this 'chaotic' situation has been the cause of many trials and tribulations over the past 30 years.

45 Sometimes people will bring non-food items to the spirit/ancestors, such as clothes, tais, and so on. The spirit/ancestor is treated like a living person with the same needs. 


\section{Restoration}

Since independence, the diverse house-based descent groups of suco Babulo have been engaged in the process of returning to their pre-1975 settlements (baha) and rebuilding their ancestral cult houses. Darlari elders, and members of the Darlari descent group in general, consider the return to their settlement of origin at Baha Liurai an important and necessary step in re-establishing their credentials as 'lords of the land'. The Baha Liurai is the most sacred of all sites in Darlari narratives of origin. It is considered to be the burial place of the ina ama (mother and father) of the Mane Hitu. Access to the summit is absolutely prohibited unless accompanied by ritual authorities. Symbolically, Baha Liurai not only serves to legitimate Darlari precedence in relation to other groups living in the area, but also confirms the emplaced nature of their authority. Informants reported that during discussions as to whether or not the settlement should be rebuilt on its original site, closer to the summit of the Baha Liurai, or on a more accessible site, the elders agreed that it should be moved closer to the main road (from Uatolari to Quelicai) so that people would be made aware that they were 'passing through sacred land'. ${ }^{46}$

As early as August 2000, work began on rebuilding the main Darlari ritual houses, the uma buti and uma ita. Elders describe the ma buti as the principal uma luli. It 'belongs' to the whole community - understood as all those living within the Darlari domain - but is 'owned' by the Darlari. More specifically, this structure symbolically represents the 'origin' house of the Darlari ancestors. The uma ita, on the other hand, is described as an uma ukun or ruling house where Darlari headmen traditionally stored symbols of political power called rotan, which they distributed to subsidiary houses and allied groups. Both structures retain sacred heirlooms believed to have belonged to the ancestors and passed down from generation to generation. It is believed that the essence of the ancestors continues to live through these objects and inhabits specific spaces within uma luli. During collective rituals, food offerings, water, bua and malus (areca nut and betel pepper leaf) are placed within these sacred spaces and emerge transformed to be redistributed to members of the community. Areca nut and betel pepper leaf stored in these houses are believed to have special protective qualities. They are used in collective rituals as a marker of membership of the group but also to protect visitors to the area or in healing rituals. ${ }^{47}$

Following the completion of the uma buti and uma ita, representatives of all the house-based descent groups living on Darlari lands and neighbouring allies (namely, the ki itana and ki butana) were invited to take part in a rare ceremony

\footnotetext{
46 Younger members of the family stated that they felt that the site should be moved closer to the road and to the water source given the age of those who would be returning to the settlement.

47 Unlike the uma ita, the uma buti is not used as a meeting house and is not permanently lived in.
} 
of ritual sacrifice to the ancestors on the summit of Baha Liurai. The elders explain that the purpose of the ceremony is threefold: to visit the burial site of the ancestors and communicate within them; to thank the ancestors for watching over the people living on their sacred land; and to ask for their continued protection and generosity. This ceremony last took place immediately prior to the community's displacement towards Matebian in late 1976. Prior to 1976, the Darlari elders stated that the ceremony took place every five to ten years or 'when it was deemed necessary'. During the initial stages of the ceremony, there was considerable debate and negotiation regarding various aspects of the 'order of things'. In part, this was due to the fact that none of the elders who had directed the last ceremony is alive, but this contestation also forms an integral part of the nature of relations between the various house-based groups now living on Darlari lands. ${ }^{48}$

In essence, the ceremony is the re-enactment and representation of key discourses of origin and precedence that underpin the social organisation of house-based descent groups within the Darlari domain. During the course of the ceremony, key notions of ancestry, attachment to place, histories of migration and settlement and networks of alliance are all acknowledged within a single visual narrative.

From the Darlari perspective, the ceremony begins at the uma buti and the uma ita. During this first stage of the ceremony, the main sacrificial offerings - rice, areca nut and 'holy' water-are brought to or taken from inside the um buti and handed to the senior members of the diverse Darlari lineages, sub-lineages and their affines. The Kabu Rai then directs those participating in the ceremony to form into single file according to rank, with senior members of the 'elder' houses preceding the 'younger' house members. Once the group is assembled, they begin the procession to the summit of Baha Liurai.

Representatives of the sibling Beli and Darlari descent groups approach the Baha Liurai from their separate domains. At a location called ita mata, kai hene (door and gate), they are met by representatives from the Burmeta clan, who have made their way there from their principal cult house at Burosoba. ${ }^{49}$ Together the group continues their 'pilgrimage' to the ancestral burial site on Baha Liurai. The Makaer Luli from Burlalu and the Darlari elders are responsible for 'opening the door' to the summit before all others may pass. The Makaer Luli carries with him sacra from the uma luli at Burlalu and acolytes from the houses of Asu Rati Reino and Asu Rati Liurai lead the way towards the summit of Baha

\footnotetext{
48 To a certain extent, the ceremony at Baha Liurai provides a space for a degree of 'theatre' where representatives of different groups attempt to redefine their role within the broader group. One such discussion involved the placing of the ex-nurep in relation to the former chefe suco. During the Indonesian occupation, the nurep represented a covert counterpart to the Indonesian-installed village leadership, kepala desa.

49 See previous note on the ritual name given to the Burmeta clan.
} 
Liurai. They are followed by the Bu Dato of Beli and Darlari and the liurai of Aha Bu'u and Kotanisi. Other senior members of the community follow carrying animals and rice, which will be offered to the ancestors and shared amongst all those present. Sacred areca nut, betel pepper leaves and water drawn from one of the we-mata luli (sacred springs) are also carried.

An area of forest is cleared on the summit as preparations for the night-long vigil and communal feast begin. Two altars are prepared where food will be laid out for the ina ama Beli Darlari (mother, father Beli Darlari), the mythical 'original' couple. Once the food is prepared, it is laid out on the altars. According to custom, all those present are required to stay awake and alert throughout the night in solemn vigil, remembering the ancestors and members of the community who cannot be present. There are strict rules regarding behaviour throughout the ceremony. These include: no alcohol, no areca nut chewing, no smoking, no defecation and no swearing or inappropriate conduct between men and women. Throughout the night, representatives of the Darlari uma kain (sub-lineages) ensure that no-one falls asleep or breaks these prohibitions. Every so often, men from the houses of Asu Rati Reino and Asu Rati Liurai beat the sides of the altar with bamboo sticks to keep malignant $b u^{\prime} u$ away.

At sunrise, following the sharing of food that is distributed according to precedence, the spokesperson for the Darlari elders, supported by the Kabo Rai, reminds all those present of their social and moral obligations to the ancestors and the rea mumu, rea uato (lord of the land). This proclamation includes statements of behavioural norms and practices regarding social interaction between men and women as well as descent groups. It also reiterates any prohibitions regarding access to certain areas of land, forest or other natural resources and reminds those present of protocols pertaining to land use such as those determining the season for certain agricultural tasks such as clearing, burning, planting and harvesting. Once these rules - collectively known as luli or bandu (Tetun) - have been declared, all the participants prepare to leave the Baha Liurai in single file and in silence without turning back. The last to leave must be a Darlari ritual specialist who 'closes' the ita mata (door) through which they passed the day before.

The ceremony at Baha Liurai provides a vivid visual medium for understanding the role, function and status of each house-based group and the nature of the relationships that bind house-based groups within a single domain. Critically, the ceremony at Baha Liurai also constitutes a 'renewal' or 'reaffirmation' of the bond that exists between the ancestors and members of the different house-based groups. The ritual (re)connection with the founding ancestors was considered indispensable for the restoration of the 'proper order of things' after 24 years of war, occupation and displacement. The time, effort and resources invested in the ceremony at Baha Liurai suggest that the community is committed to 
maintaining the social and moral order within which the different housebased groups are situated, including the rights, duties and obligations that this implies (cf. McWilliam 2005). Since independence, communities throughout Timor-Leste have been engaged in processes of restoration and renewal similar to those described in this chapter. Many communities have felt a great degree of pride in the reconstruction of their ancestral cult houses and the revival of cultural performances. ${ }^{50}$ Furthermore, for many rural communities, the (re)turn to custom has provided a sense of security and continuity as a counterpoint to the violence and disruption caused by the political turmoil centred on the nation's capital. ${ }^{51}$ Beyond the interest of anthropologists and other scholars engaged in understanding the nature of social relations in a time of change, the 'resurgence', persistence or resilience of customary forms of constructed sociality provides a fertile field of study into understanding the strategies and struggles of communities as they seek to re-establish themselves after years of war and displacement.

\section{Acknowledgments}

Research for this chapter took place between 2004 and 2008. A major part of the research was conducted under the auspices of an Australian Research Council Discovery Grant for a joint legal-anthropological research project on customary land tenure in Timor-Leste at The Australian National University. My thanks to friends and advisors in Babulo - in particular, the elders of the Darlari descent group Senhores Carlos, Anacleto and Gaspar, the 'eldest sons' Miguel, Lorenzo, Zeferino, liurai Joaquim, Ama Bo'ot, Ama Ki'ik, Maria Alexandrina and Felismina. Also thanks to Andrew McWilliam for encouraging me to write and Josh Trindade for his constant support and advice on all things Naueti.

\footnotetext{
50 RTTL (Radio Telivisaun Timor-Leste) has been invited to film uma lulik inaugurations and other ceremonies in a number of locations across the country. Although few communities where these ceremonies have taken place are able to watch RTTL - there is no power, no television sets, no reception - many still feel great pride in the fact that their histories, houses and land are being viewed at the national level.

51 In 2006 and 2007, what began as a dispute within the armed forces led to a general breakdown of law and order and the displacement of tens of thousands of people. Most of the violence and displacement was centred on the capital, Dili.
} 


\section{References}

Babo-Soares, D. 2004, 'Nahe Biti: the philosophy and process of grassroots reconciliation (and justice) in East Timor', Asia Pacific Journal of Anthropology, vol. 5, no. 1, p. 15.

Bovensiepen, J. 2009, 'Spiritual landscapes of life and death in the central highlands of East Timor', Anthropological Forum: A journal of social anthropology and comparative sociology, vol. 19, no. 3, pp. 323-38.

Brown, A. M. 2009, 'Security, development and the nation-building agendaEast Timor', Conflict, Security and Development, vol. 9, no. 2, pp. 141-64.

Commission for Reception, Truth and Reconciliation in Timor-Leste (CAVR) 2005, Chega!: The report of the Commission for Reception, Truth and Reconciliation in Timor-Leste-Executive summary, Commission for Reception, Truth and Reconciliation in Timor-Leste, Dili.

De Menezes, F. 2006 [1968], Encontro de Culturas em Timor-Leste, Crocodilo Azu, Dili.

Direcção Nacional de Estatística 2004, Census of Population and Housing. D. N. d. Estatística, Direcção Nacional de Estatística, Dili.

Fitzpatrick, D. and Barnes, S. 2010, 'The relative resilience of property: first possession and order without law in East Timor', Law and Society Review, vol. 45 , no. 2 .

Fitzpatrick, D., McWilliam, A. and Barnes, S. 2008, 'Policy notes on customary tenures in Timor Leste', East Timor Law Journal.

Fox, J. J. 1994, 'Reflections on hierarchy and "precedence"', History and Anthropology: Special Issue, vol. 7, nos 1-4, pp. 87-108.

Fox, J. J. 1995, 'Installing the 'outsider' inside: The exploration of an epistemic Austronesian cultural theme and its social significance'. The First Conference of the European Association for Souteast Asian Studies: Local Transformation and Common Heritage in Southeast Asia. Leiden University.

Fox, J. J. and Sather, C. A. (eds) 1996, Origins, Ancestry and Alliance: Explorations in Austronesian ethnography, Department of Anthropology, The Australian National University, Canberra.

Gunter, J. 2007, 'Communal Conflict in Viqueque and the 'Charged' History of '59'. The Asia Pacific Journal of Anthropology, vol 8, pp. $27-41$ 
Gunter, J. 2008, Violence and 'being in history' in East Timor: local articulations of colonial rebellion, MA thesis, Department of Anthropology, Instituto Superior de Ciências do Trabalho e da Empresa, Lisbon.

Hicks, D. 2007, 'Community and nation-state in East Timor', Anthropology Today, vol. 23, no. 1, pp. 13-16.

Hohe, T. 2002, 'The clash of paradigms: international administration and local political legitimacy in East Timor', Contemporary Southeast Asia, vol. 24, no. 3, p. 21.

Lewis, E. D. 1996, 'Origin structures and precedence in the social orders of Tana 'Ai and Sikka', in J. J. Fox and C. A. Sather (eds), Origins, Ancestry and Alliance: Explorations in Austronesian ethnography, Department of Anthropology, The Australian National University, Canberra.

McWilliam, A. 2005, 'Houses of resistance in East Timor: structuring sociality in the new nation', Anthropological Forum: A journal of social anthropology and comparative sociology, vol. 15, no. 1, pp. 27-44.

McWilliam, A. 2006, 'Fataluku forest tenures and the Conis Santana National Park in East Timor', in T. Reuter (ed.), Sharing the Earth, Dividing the Land: Land and territory in the Austronesian world, ANU E Press, Canberra.

McWilliam, A. 2007, 'Harbouring traditions in East Timor: marginality in a lowland entrepot', Modern Asian Studies, vol. 41, no. 6, pp. 1113-43.

McWilliam, A. 2008, 'Fataluku healing and cultural resilience in East Timor', Ethnos, vol. 73, pp. 217-40.

Meitzner Yoder, L. S. 2005, Custom, codification, collaboration: integrating the legacies of land and forest authorities in Oecusse enclave, East Timor, PhD thesis, Yale University, New Haven, Conn., pp. xviii, 370.

Palmer, L. 2007, 'Developing Timor Leste: recognising the role of custom and tradition', in Exploring the Tensions of Nation Building in East Timor, University of Melbourne, Melbourne.

Traube, E. G. 2007, 'Unpaid wages: local narratives and the imagination of the nation', Asia Pacific Journal of Anthropology, vol. 8, pp. 9-25.

Trindade, J. 2008, 'Reconciling conflicting paradigms and East Timorese vision of the ideal state', in D. Mearns (ed.), Democratic Governance in East Timor: Reconciling the local and the national, Charles Darwin University Press, Darwin.

Vischer, M. P. 2009, Precedence: Social differentiation in the Austronesian world, ANU E Press, Canberra. 